\title{
THE USE OF CIPROFLOXACIN FOR DECONTAMINATION OF! LSCC-H 32 CELL LINE OF CHICKEN EMBRYONAL FIBROBLASTS CONTAMINED BY MYCOPLASMA ARGININI
}

\author{
O. FISCHER, Marie HÃJKOVÁ, Zuzana HOŘ́nOVÃ, Květoslava JURMANOVÃ \\ and Dagmar ZENDULKOVÁ \\ Veterinary Research Institute, 62132 Brno
}

Received August 2, 1991

\begin{abstract}
Fischer O., Marie Hájková, Zuzana Hořínová, Květoslava Jurmanová, Dagmar Zendulková: The Use of Ciprofloxacin for Decontamination of LSCC-H 32 Cell Line of Chicken Embryonal Fibroblasts Contaminated by Mycoplasma arginini. Acta vet. Brno, 61, 1992: 51-56.

Cells of line LSCC-N 32 of chicken embryonal fibroblasts contaminated by $M y-$ coplasma arginini were decontaminated by culture in a medium supplemented with $10 \mu \mathrm{g}$ per ml of ciprofloxacin during 10 passages ( 42 days). During another 30 passages (112 days) in an antibiotic-free medium no mycoplasmas were detected in repeated examination by the fluorescence method, culture in a liquid medium supplemented with glucose, urea or arginine, culture in a solid medium or by scanning electron microscopy. Decontamination by ciprofloxacin neither changed morphological properties of cells nor increased number of aberrant mitoses. The LSCC-H 32 cells, decontaminated by ciprofloxacin, showed on day 5 of culture by $51.2 \%$ higher proliferation index compared with cells of the same line contaminated by M. arginini.
\end{abstract}

Proliferation index, the finorescence method, mitosis

Mycoplasmas, entering the cell cultures with contaminated sera (Barile and Kern 1971) and in case of unsufficient preventive measures while working with cell cultures (O'Connell et al. 1964; McGarrity 1976; Machatková et al. 1983) have an adverse effect on the metabolism and properties of the cultured cells (Stanbridge 1971; Fogh 1973). The most dangerous mycoplasmas are those using in a large extent arginine from the culture media (Sa saki et al. 1984).

Decontamination of cell cultures is very difficult and only methods destroying reliably mycoplasmas without any harmful effect on cell cultures can be used. Of many antibiotics used against mycoplasmas in cell cultures (Gori and Lee 1964; Perlman et al. 1967; D'Yakonov et al. 1981; Sánchez and Pérez 1983; Rodríguez et al. 1987) ciprofloxacin proved to be very efficient (Ridgway et al. 1984; Schmitt et al. 1988).

Cell line LSCC-H 32 of chicken embryonal fibroblasts (Lange 1980; Kaaden et al. 1982) was used in our laboratory together with primary cultures of chicken embryonal fibroblasts of the isolation of avian reoviruses (Pospísil et al. 1988). The line was unintentionally contaminated by Mycoplasma arginini in the laboratory.

No data have been published so far on the decontamination of avian cell cultures by ciprofloxacin. As in previous experiments good effect of ciprofloxacin against Mycoplasma orale in the culture of swine kidney cells was confirmed (Fischer et al. 1989a), we tried to decontaminate in the same way the line LSCC-H 32 of chicken embryonal fibroblasts. In the same way we determined if in avian cells, which are more demanding for culture conditions than mammalian ones, undesirable changes of morphological, growth and cytogenetic properties did not occur during the decontamination by ciprofloxacin.

\section{Materials and Methods}

Culture of cells

The LSCC-H 32 cells contaminated by Mycoplasma arginini were cultured in Mueller, Legroux and Roux flasks with capacity of $300 \mathrm{ml}$ at $37^{\circ} \mathrm{C}$ in MEM medium (Minimal Eagle's Medium, 
Institute of Sera and Vaccines, Prague) supplemented with $10 \%$ bovine serum, penicillin (100 I.U, per $\mathrm{ml})$ and streptomycin $(100 \mu \mathrm{g}$ per $\mathrm{ml})$. The cells were reseeded after $3-5$ days of culture when a complete monolayer was formed. Before reseeding, the cells were released enzymatically with a solution containing 0.2 . $\%$ trypsin and $0.02 \%$ versene.

\section{Mycoplasma detection}

Mycoplasmas were detected in the LSCC-H 32 culture prior to, during and after decontamination by culture in liquid media supplemented with glucose, urea or arginine, culture in a solid medium (Jurmanová and Machatková 1986), the fluorescence method by Chen (1977), modified by Machatková et al. (1986) and scanning electron microscope Tesla BS 300 (Fischer et al. 1991). Indirect immunofluorescence method (Rosendal and Black 1972) was used for the determination of mycoplasma species.

\section{Decontamination}

Ciprofloxacin (BAYER, Leverkusen, Testsubstanz BAY o 9867 ), sterilized by ${ }^{60}$ Co irradiation (25 kGy) was used for decontamination. The sterile test substance containing $827 \mu \mathrm{g}$ of active substance per $1 \mathrm{mg}$ was dissolved in MEM medium with $10 \%$ fetal calf serum, so that the resulting active substance concentration was $10 \mu \mathrm{g}$ per $\mathrm{ml}$. No other antibiotics, except for ciprofloxacin, were added to the medium. The cells were cultured at $37^{\circ} \mathrm{C}$ for 10 passages ( 42 days).

\section{Decontamination efficiency checks}

The decontaminated cells were cultured in MEM medium with $10 \%$ fetal calf serum without antibiotics for 30 passages (112 days). During this period the cells were examined repeatedly using the methods for mycoplasma detection (see Mycoplasma detection).

Certain measures were taken in the course of cultivation to prevent a new contamination by mycoplasmas (Fischer et al. 1989).

\section{Cytogenetic examination}

Samples for cytogenetic examination were prepared using a modified method by Lemáková (1988). Cells were seeded to Mueller flasks with $5 \mathrm{ml}$ medium at a density $1 \times 10^{6}$ cells per ml. Colchicine $(0.1 \mathrm{ml}$ of $0.01 \%$ solution) was added to the culture medium after $6 \mathrm{hrs}$ of cultivation at $37^{\circ} \mathrm{C}$ and after another $10 \mathrm{hrs}$ of cultivation the cells were released from the glass and cell suspension was centrifuged at $1000 \mathrm{rpm}$ for 10 minutes. Cells in the sediment were resuspended in $5 \mathrm{ml}$ of $0,75 \%$ solution of sodium citrate preheated to $37^{\circ} \mathrm{C}$ and hypotonized at this temperature for 25 minutes. After centrifugation the cells in sediment were fixed with a mixture of methanol and glacial acetic acid $(3: 1)$ for 30 minutes and then twice for 10 minutes with a fresh fixation solution. Suspension of fixed cells was dropped on cooled, defatted slides $\left(4^{\circ} \mathrm{C}\right)$, the drops were dried at room temperature and the next day stained with $5 \%$ solution of Giemsa dye in a phosphate buffer (pH 6.8).

The chromosomes were counted in propagating cells in 100 metaphases and disorders in cell propagation in 200 metaphases.

Comparison of morphological and growth properties of contaminated and decontaminated cells

Morphological properties of cells were evaluated in every day examination of cultures by light in'ersion microscope at a magnification $630 \times$. To compare the growth properties, the cells were seeded into plasti- Petri dishes, $60 \mathrm{~mm}$ of diameter, with $5 \mathrm{ml}$ MEM medium supplemented with $10 \%$ colostrum-deprived newborn calf serum, penicillin (100 I.U. per ml) and streptomycin $(100 \mu \mathrm{g}$ per $\mathrm{ml})$ at a density $0.1 \times 10^{5}$ cells per ml. The cells were cultured in an atmosphere with $5 \% \mathrm{CO}_{2}$ at $37{ }^{\circ} \mathrm{C}$ for 5 days. Every day the cells in three dishes of each of the compared groups were released and summarized. The experiment has been repeated three times and the results of three independent experiments were evaluated by Student's t-test.

\section{Results}

In the course of culture of medium from the contaminated LSCC-H 32 cells in liquid media supplemented with glucose, urea and arginine, splitting of arginine in the medium with arginine was observed, resulting in change of medium colour from orange to violet. Culture on solid medium under anaerobic conditions yielded colonies of mycoplasmas, determined by indirect fluorescence method as Mycoplasma arginini. 


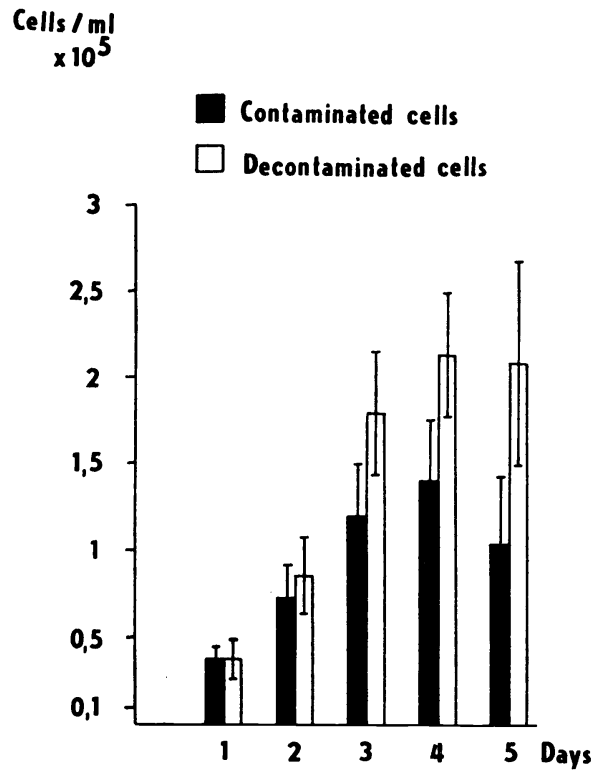

Fig. 3: Comparison of growth of contaminated and decontaminated LSCC-H 32 cells
Numerous small, brightly fluorescent bodies containing DNA in cell cytoplasm were observed by the fluorescence method.

Scanning electron microscopy revealed on cell surfaces among numerous microvilli, spherical bodies, sometimes with central depressions, resembling human erythrocytes (Plate XXVIII., Fig. 1).

Neither cytopathic effect nor growth retardation was observed in cell cultures in medium with ciprofloxacin. The fibroblastoid morphology of cells remained preserved.

Even in a course of cell culture in medium with ciprofloxacin (10 $\mu \mathrm{g}$ per $\mathrm{ml}$ ), mycoplasmas disappeared from the culture, so that they were not detected in the 4th, 9th and 10th passages. Mycoplasmas in the culture were not detected by any of the above mentioned methods, even at the checks of decontamination efficiency, when decontaminated cells were cultivated in an antibiotic-free medium for 30 passages (112 days).

Cytogenetic examination did not show any significant changes in dispersion, modal and average numbers of chromosomes. Number of aberrant mitoses did not increase (Table 1).

Decontaminated cells had by $33.3 \%$ higher proliferation index compared with cells contaminated by $M$. arginini on day 3 , and by $34.1 \%$ and $51.2 \%$ on days 4 and 5 respectively $(P<0.01)$ (Fig. 3$)$.

Table 1

Cytogenetic values of LSCC-H 32 cells contaminated by Mycoplasma arginini prior to and after decontamination by ciprofloxacin

\begin{tabular}{|c|c|c|c|}
\hline $\begin{array}{l}\text { Number of tested } \\
\text { mitoses }\end{array}$ & Value & $\begin{array}{l}\text { Cells prior to } \\
\text { decontamination }\end{array}$ & $\begin{array}{c}\text { Cells after } \\
\text { decontamination* }\end{array}$ \\
\hline 100 & $\begin{array}{l}\text { Dispersion of chromosome number } \\
\text { Average number of chromosomes } \\
\text { Modal number of chromosomes }\end{array}$ & $\begin{array}{c}38-51 \\
43.9 \pm 2.6 \\
42 \text { (in } 24 \% \text { of mitoses) }\end{array}$ & $\begin{array}{c}41-51 \\
46.6 \pm 2.4 \\
48 \text { (in } 22 \% \text { of mitoses) }\end{array}$ \\
\hline 200 & $\begin{array}{l}\text { Aberrant mitoses } \\
\text { Chromatide breaks } \\
\text { Isochromatide breaks } \\
\text { Exchanges } \\
\text { Dicentric chromosomes } \\
\text { Number of breaks per } 1 \text { mitosis** }\end{array}$ & $\begin{array}{l}10(5 \%) \\
4 \\
1 \\
0 \\
2 \\
0.045\end{array}$ & $\begin{array}{l}10(5 \%) \\
1 \\
0 \\
16 \\
7 \\
0.35\end{array}$ \\
\hline
\end{tabular}

*) After 10 passages in medium with ciprofloxacin '10 $\mu \mathrm{g}$ per $\mathrm{ml}$ ) and another 30 passages in antibiotic-free medium

**) Number of breaks per 1 cell comprises chromatide breaks, isochromatide breaks, exchanges and dicentric chromosomes, one exchange or one dicentric chromosome were taken as 2 breaks. 


\section{Discussion}

Ciprofloxacin is an antibiotic acting as inhibitor of bacterial enzyme gyrase (DNA-topoisomerase II) which is necessary for bacterial DNA winding. Schmitt et al. (1988) reported that ciprofloxacin at a dose $10 \mu \mathrm{g}$ per $\mathrm{ml}$ was efficient against Mycoplasma hyorhinis, $M$. gallisepticum, M. orale, M. salivarium, M. hominis, M. fermentans and $M$. arginini in artificially infected cultures of myeloma cells. Jurmanová et al. (1990) found out that $10 \mu \mathrm{g}$ per $\mathrm{ml}$ of ciprofloxacin were not toxic for primary cultures of chicken embryonal fibroblasts, even after ${ }^{60} \mathrm{Co}$ sterilization. The same batch and the same dose of ciprofloxacin were used as in experiment carried out by Jurmanová et al. (1990), without any toxic effect on cells observed.

The LSCC-H 32 cells were obtained by transformation of chicken embryonal fibroblasts by culture at $32{ }^{\circ} \mathrm{C}$ (Lange 1980; Kaaden et al. 1982).

Cytogenetic examination of LSCC-H 32 cells prior to decontamination showed that a heteroploid line is concerned, with lower average number of chromosomes $(43.9 \pm 2.6)$ than the usual number of chromosomes $(2 n=78)$ in caryotype of Gallus domesticus as stated by Guevara et al. (1985). Decontamination of cell line neither changed significantly the average number of chromosomes $(46.6 \pm 2.4)$ nor number of aberrant mitoses. Increased number of exchanges and related increased number of breaks per 1 mitosis night be caused by several culture conditions.

Machatková et al. (1983) obtained significant improvement of mammalian cell cultures and increasing of proliferation indices by decontamination. The same effect has been obtained at decontamination of LSCC-H 32 cell line by ciprofloxacin. The fact that decontaminated cells of LSCC-H 32 cell line had a two-fold proliferation index compared with cells contaminated by $M$. arginini, confirms a great economic importance of using of mycoplasma-free cell cultures.

However, cell line decontamination could be successful only under conditions preventing new contamination of cells by mycoplasmas (Fischer et al. 1989b). Machatková et al. (1983) mentioned that if preventive measures against mycoplasma contamination were not taken in course of laboratory work with cell cultures, mycoplasmas were detected by the fluorescence method in originally mycoplasma-free cultures already after 5 passages.

The use of antibiotics, even very efficient ones, is not in itself a reliable protection of cell cultures against mycoplasmas, because new strains, resistent against antibiotics, can be formed (Rahman et al. 1967).

Not only a single examination method should be used for mycoplasma detection in cell cultures, but it is advisable to use at least two methods at the same time (Polak - Vogelzang et al. 1987).

Mycoplasmas in cell cultures in antibiotic-free media propagate well and can be detected by a combination of the fluorescence method and culture methods (Jurmanová and Machatková 1986). Scanning electron microscopy serves only as a supplementary method, because it is very difficult to differentiate mycoplasmas adhered to cell surfaces and cell microvilli (Fischer et al. 1991). The sensitivity of decontaminated cell line LSCC-H 32 to avian viruses will be the subject of another research project. 


\section{Acknowledgement}

The authors thank Mrs. Helena Mušková for making the cytogenetic preparations and Mr. Jiři Kudrna for technical assistance at scanning electron microscopy.

\section{Použití ciprofloxacinu $\mathbf{k}$ dekontaminaci buněčné linie kuřecích embryo- nálních fibroblastů LSCC-H 32 kontaminované Mycoplasma arginini}

Buňky linie kurecích embryonálních fibroblastů LSCC-H 32 kontaminované Mycoplasma arginini byly dekontaminovány kultivací v mediu s $10 \mu \mathrm{g} / \mathrm{ml}$ ciprofloxacinu po dobu 10 pasáži (42 dni). Během dalších 30 pasáži (112 dní) v mediu bez antibiotik nebyla mykoplazmata prokázána opakovaným vyšetřováním fluorescenční metodou, kultivací $\mathrm{v}$ tekutých mediích glukózou, ureou nebo argininem, kultivací na pevné půdě ani rastrovaci elektronovou mikroskopií. Dekontaminace ciprofloxacinem nezměnila morfologické vlastnosti buněk ani nezvýšila počet aberantních mitóz. Buňky LSCC-H 32 dekontaminované ciprofloxacinem měly v 5. dnu po nasazení o $51,2 \%$ vyšší proliferační index než buňky téže linie kontaminované Mycoplasma arginini.

\section{Применение ципрофлоксацина для деконтаминирования клеточной пинии куриных эмбриональных фибробластов LSCC-H 32, контаминированной Mycoplasma arginini}

Клетки линии куриных эмбриональных фибробластов LSCC-H 32 контаминированные Mycoplasma arginini, были деконтаминированы культивацией в среде с $10 \mathrm{mkr} / \mathrm{Mn}$ ципрофлоксацина в течение 10 пассажей (42 сүток). В ходе следующих 30 пассажей (112 сүток) в среде без антибиотиков микоплазмы не были выявлены повторным исследованием флуоресцентным методом, культивированием в жидкой среде с глюкозой, уреей или аргинином, культивацией на прочной почве, ни растровой электронной микроскопией. Деконтаминирование ципрофлоксацином не изменило морфологические свойства клеток и не увеличило также число аберрантных митозов. Деконтаминированные ципрофлоксацином клетки LSCC-H 32, отличались на 5 сутки после применения на $51,2 \%$ более высоким индексом пролиферации по сравнению с клетками той же линии, контаминированными Мусоplasma arginini.

\section{References}

BARILE, M. F. - KERN, J.: Isolation of Mycoplasma arginini from commercial bovine sera and its implication in contaminated cell cultures. Proc. Soc. exp. Biol. Med., 138, 1971: 432-437 CHEN, T. R.: In situ detection of mycoplasma contamination in cell cultures by fluorescent Hoechst 33258 stain. Exp. Cell Res., 104, 1977: 255-262

D'YAKONOV, L. P.-POZDNYAKOVA, A. A.-GOLOLOBOVA, M. T.-GRITSENKO, V. V.-SUKHAREVA, N. N.: Rezul'taty issledovanii po diagnostike mikoplazma-kcntaminatsii i dekontaminatsii kul'tur kletok. Trudy Vses. Inst. exp. Vet. (Moscow), 53, 1981; $63-77$ 
FISCHER, O.-GRANÁTOVÁ, M.-HÁJKOVÁ, M.-NEVORÁNKOVÁ, Z. - JURMANOVÁ, K.: Detection of mycoplasmas in cultures of myeloma cell lines and hybridomas by fluorescence method using Vero cells as indicators. Acta vet. Brno, 60, 1991: 41-49

FISCHER, O.-GRANÁTOVÁ, M. - NEVORÁNKOVÁ, Z. - HOǨ́NOVÁ, Z. - RUBES, J. URBANOVÁ, J. - JURMANOVÁ, K. - HÁJKOVÁ, M. - KOSKOVÁ, S. - VALfČEK, L. POSPÍSIL, Z. - HORNICH, M.: Charakteristika vybraných buněčných linií uložených v bance buněčných kultur. (Project report.) Brno, Veterinary Research Institute 1989a, 3 I p.

FISCHER, O.-JURMANOVÂ, K.-HÁJKOVÁ, M.: Kultivace buněčných linií bez mykoplazmat. Čs. fysiol., 38, 1989b, 425.

FOGH, J.: Contamination in tissue culture. New York, Academic Press 1973, 288 p.

GORI, G. B. - LEE, D. Y.: A method for eradication of Mycoplasma infections in cell cultures. Proc. Soc. exp. Biol. Med., 117, 1964: 918-921

GUEVARA, G. V.-NICOLOV, G.-BALMASEDA, G. C. -RODRÍGUEZ, P. M.: Cariotipo normal y cariograma en Gallus domesticus Rev. Prod. Anim, 1, 1985: 85-90

JURMANOVÁ, K.-MACHATKOVÁ, M.: Detection of mycoplasmas in cell cultures and biologicals. Arch. exp. Vet. Med. (Leipzig), 40, 1986: 136-141

JURMANOVÁ, K.-STTĚPÁNEK, I.-FISCHER, O.-HÁJKOVÁ, M.-VIKLICKÝ, V.: Databanka buněčných kultur a hybridomů v CSFR. (Project report.) Brno, Veterinary Research Institute 1990, $19 \mathrm{p}$.

KAADEN, O. R.-LANGE, S.-STIBUREK, B.: Establishment and characterization of chicken embryo fibro'slast clone LSCC-H 32. In Vitro, 18, 1982: 827-834

LANGE, S.: Etablierung einer permanenter Hühnerfibroblastenlinie. Hannover, Institut für Virologie der Tierärztlichen Hochschule $1980,67 \mathrm{p}$.

LEMÁKOVÁ, S.: Metodika vyšetrovania chromozomov kostnej drene hydiny. In: Metody analýzy chromozomù. Brno. Cytogenetická sekce ČSZ při CSAZ 1988, 164 p.

MACHATKOVÁ, M.-CHLUPOVÁ, L.-JURMANOVÁ, K.-HAMPL, J.-MÁDR, V.: Vývoj metod přispívajících ke standardizaci buněčných substrátů používaných ve výzkumu a diagnostice virových chorob. (Project report.) Brno, Veterinary Research Institute 1983, 29 p.

MACHATKOVA, M. - JURMANOVÁ, K.-HAMPL, J.-ŠNEJDAR, V.: Spontánní infekce buněčných linií mykoplazmaty a její detekce fluorescenční metodou. Vet. Med. (Praha), 31, 1986: 477-485

McGARRITY, G. J.: Spread and control of mycoplasmal infection of cell cultures. In Vitro, 12, 1976: $643-648$

O'CONNEL, R. G.-WITTLER, R. G.-FABER, J. E.: Aerosols as a source of widespread mycopl isma contamination of tissue cultures. Appl. Microbiol., 12, 1964: 337-342

PERLMAN, D.-RAHMAN, S. B. - SEMAR, J. B.: Antioiotic control of mycoplasma in tissue culture. Appl. Microbiol., 15, 1967: 82-85

POLAK-VOGELZANG, A. A.-BRUGMAN, J.-REIJGERS, R. : Comparison of two methods for detection of Mollicutes (Mycoplasmatales and Acholeplasmatales) in cell cultures in the Netherlands. Antonie van Leeuwenhoek, 53, 1987; 107-118.

POSPÍŚIL, Z.-ZENDULKOVÁ, D.-SMfD, B.: Výskyt a charakteristika nových virových onemocnění hrabavé drůbeže. (Project report.) Brno, Veterinary Research Institute 1988, $32 \mathrm{p}$.

RAHMAN, S. B.-SEMAR, J. B.-PERLMAN, D.: Antibiotic resistance in mycoplasma isolates from tissue culture. Appl. Microbiol., 15, 1967: 970

RIDGWAY, G. L.-MUNTAZ, G.-GABRIEL, F. G.-ORIEL, J. D.: The activity of ciprofloxacin and other 4-quinolones against Chlamydia trachomatis and mycoplasma in vitro. Eur. J. Clin. Microbiol., 3, 1984: 344-346

RODRÍGUEZ, R.-GARCIA, R.-ESNART, S.-RODRÍGUEZ, G.: Utilización de kanamicina y polimixin B para la descontaminación della línea celular RTV-1 infectada por micoplasma. Rvta Cub. Cienc. Vet., 18, 1987: 49-52

ROSENDAL, S.-BLACK, F. T.: Direct and indirect immunofluorescence of unfixed and fixed mycoplasma colonies. Acta path. microbiol. scand. B 80, 1972: 615-622

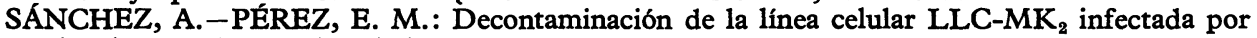
micoplasmas. Rev. Salud Anim., 5, 1983: 521 - 527

SASAKI, T. - SHINTANI, M.-KIHARA, K.: Inhibition of growth of mammalian cell cultures by extracts of arginine-utilizing mycoplasmas. In Vitro, 20, 1984: 369-375

SCHMITT, K.-DÄUBENER, W.-BITTER-SUERMANN, D.-HADDING, U.: A safe and efficient method for elimination of cell culture mycoplasmas using ciprofloxacin. J. Immunol. Meth., 109, 1988: 17-25.

STANBRIDGE, E.: Mycoplasmas and cell cultures. Bact. Rev. 35, 1971: 206-227 
Plate XXVIII.

Fischer O. et al.: The Use of ... pp. 51-56.

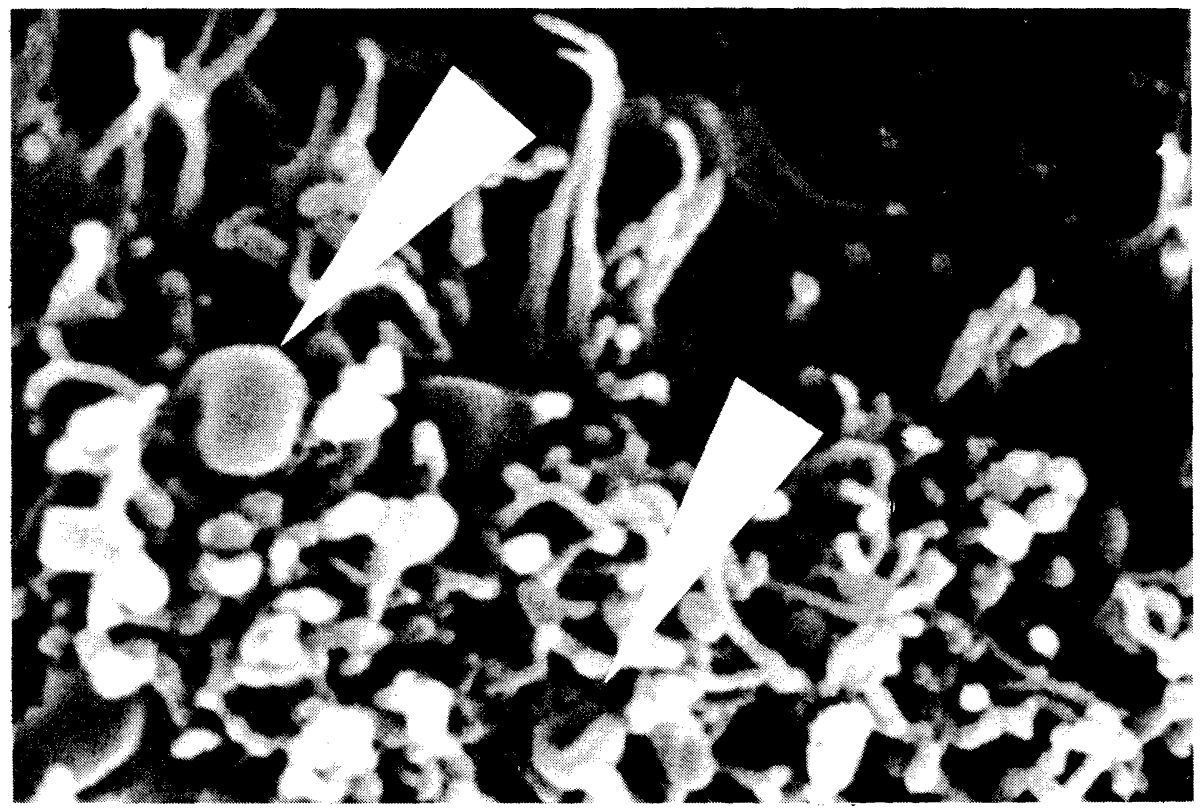

Fig. 1. Surface of LSCC-H 32 cell contaminated by Mycoplasma arginini. Attached spherical bodies, sometimes with central depressions, are observed among cell microvilli (arrows). SEM, $\times 15000$.

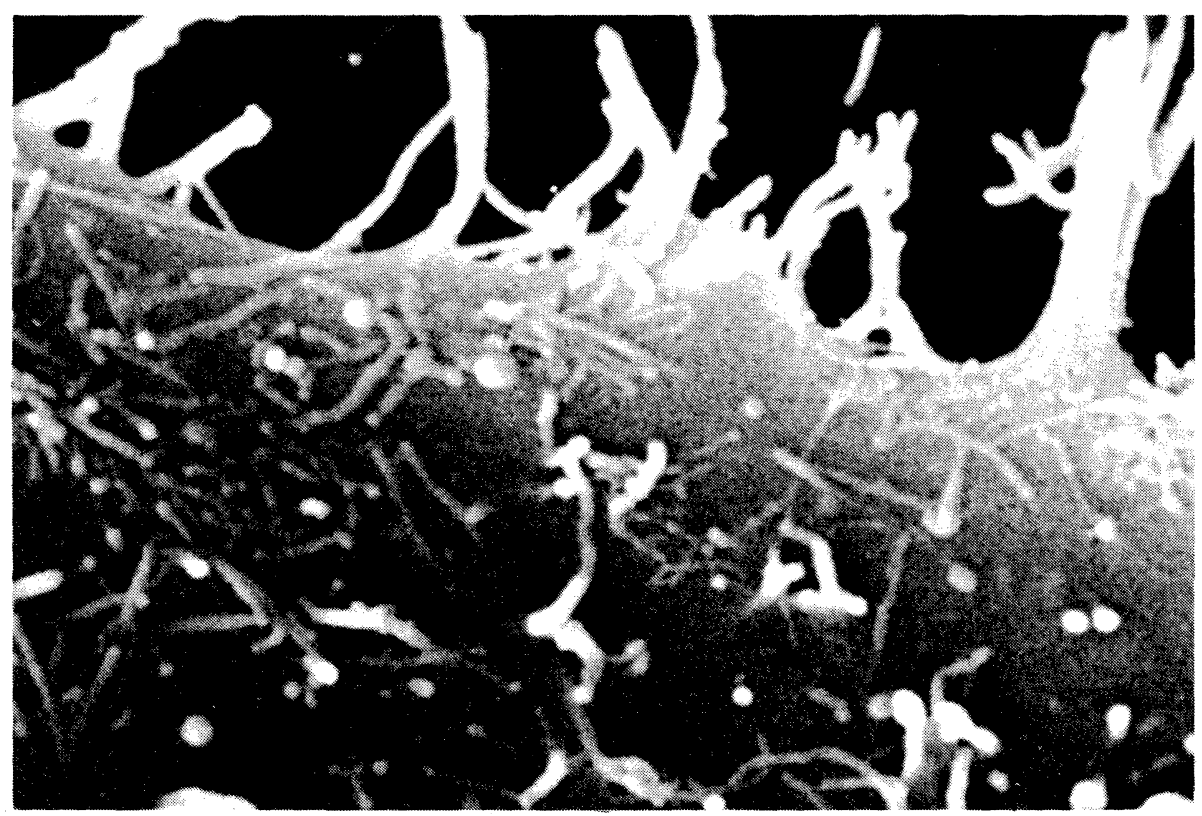

Fig. 2. Only cell microvilli are seen on the LSSC-H 32 cell surface after decontamination by ciprofloxacin. SEM, $\times 15000$. 